\title{
TIPE WISATAWAN BERDASARKAN KORELASI MOTIVASI DAN KEGIATAN DI TEMPAT WISATA (STUDI KASUS: INDONESIA)
}

\author{
Type of Tourist Based on Correlation between Motivations and \\ Activities in Tourism Destination (Case Study: Indonesia)
}

Bakri Prakarso Andi Wiyono ${ }^{1}$, Hanson E. Kusuma ${ }^{1}$, Fran Sinatra ${ }^{2}$, Angela C. Tampubolon ${ }^{3}$

Diterima: 24 Juli 2018 Disetujui: 17 Agustus 2018

\begin{abstract}
Abstrak: Pariwisata telah menjadi sektor yang berkontribusi besar di dalam perekonomian negaranegara di dunia, terutama Indonesia. Daya tarik Indonesia berasal dari berbagai potensi berupa alam, kearifan lokal, maupun buatan. Berbagai daya tarik tersebut membuat berbagai macam tipe wisatawan memiliki beragam motif untuk berkunjung dan berkegiatan di lokasi tersebut. Penelitian ini menggunakan metode campuran (kualitatif-kuantitatif) dengan strategi sekuensial prosedur. Tujuan dari penelitian ini adalah untuk menentukan tipe wisatawan berdasarkan korelasi antara motivasi berwisata dengan kegiatan wisata. Pengumpulan data dilakukan melalui kuesioner daring yang dibagikan kepada beberapa kelompok (nonprobability-convenience sampling). Data yang terkumpul selanjutnya dianalisis secara kualitatif menggunakan analisis isi dan secara kuantitatif menggunakan analisis komponen prinsip, analisis faktor, dan analisis korelasi multivariat. Hasil analisis mengungkapkan bahwa terdapat enam motivasi wisata yaitu kontemplasi, eksplorasi-sosial, restoratif, kuliner, kesempatan, dan kebaruan. Selain itu, terdapat empat kegiatan wisata yaitu kegiatan fisik, kognitif, afektif, dan petualangan. Hasil dari korelasi motivasi dan kegiatan wisata kemudian membentuk pola yang menunjukkan tiga tipe wisatawan yaitu explorer, pleasure seeker, dan adventurer.
\end{abstract}

Kata-kunci : motivasi wisata, kegiatan wisata, tipe wisatawan

Abstrak; Tourism has become a major contributing sector in the economies of many countries in the world, especially Indonesia. The attractiveness of Indonesia comes from a variety of potential such as nature, local wisdom, or artificial. Those attractions make tourist can be defined as many types based on their motives and activities. This research used mixed method (qualitative-quantitative) with sequential procedure strategy. The purpose of this study is to determine the type of tourists based on the correlation between the motivation of travel with tourism activities. Data collection was done through an online questionnaire and distributed to several groups (nonprobabilityconvenience sampling). The collected data were then analyzed qualitatively using content analysis and quantitatively using principal component analysis, factor analysis, and multivariate correlation analysis. The results of the analysis revealed that there are six tourism motivations namely contemplation, social-exploration, restorative, culinary, opportunity, and novelty. In addition, there

\footnotetext{
${ }^{1}$ SAPPK, Institut Teknologi Bandung.

${ }^{2}$ Program Studi Perencanaan Wilayah dan Kota, Institut Teknologi Sumatera

${ }^{3}$ Program Studi Arsitektur, Universitas Kristen Petra
} 
are four tourism activities namely physical activity, cognitive, affective, and adventure. The results of the correlation of motivation and tourism activities then form a pattern that shows three types of tourists such as explorer, pleasure seeker, and adventurer.

Keywords : tourism motivation, tourism activity, type of tourist

\section{PENDAHULUAN}

Wisata timbul karena adanya keunikan dari suatu tempat yang menjadi identitas. Heritage tourism, creative industries, multiculturality dan the local way of life merupakan elemen kunci yang menunjukkan identitas dari daya tarik wisata (Urošević, 2012). Yoeti (1996) mendefinisikan daya tarik atau atraksi wisata sebagai segala sesuatu yang dapat menarik wisatawan untuk berkunjung pada suatu daerah tujuan wisata, seperti alam, budaya, buatan manusia, maupun manusia. Sedangkan Undang-undang Nomor 10 Tahun 2009 mendefinisikan wisata sebagai kegiatan perjalanan yang dilakukan oleh seseorang atau sekelompok orang dengan mengunjungi tempat tertentu untuk tujuan rekreasi, pengembangan pribadi, atau mempelajari keunikan daya tarik wisata yang dikunjungi dalam jangka waktu sementara dan mendefinisikan daya tarik wisata sebagai objek yang dikunjungi ketika seseorang berwisata.

Indonesia merupakan negara dengan banyak potensi wisata yang dapat dikunjungi oleh berbagai wisatawan, baik lokal maupun mancanegara. Jumlah kunjungan wisatawan mancanegara sampai dengan Oktober 2017 sebesar 11.617 .828 wisatawan. Jumlah ini meningkat 23,55\% dibandingkan tahun 2016 dengan jumlah wisatawan mancanegara sebesar 9.403.614 wisatawan. Wisatawan paling banyak berasal dari Tiongkok, Singapore, dan Australia. Sedangkan jumlah perjalanan wisatawan lokal selama tahun 2015 mencapai 256,42 juta perjalanan yang berarti mengalami peningkatan sebesar 2,02\% dibandingkan dengan tahun 2014 dengan jumlah perjalanan 251,24 juta perjalanan. Objek wisata yang dikunjungi didominasi oleh objek wisata buatan $(40,59 \%)$, objek wisata bahari $(25,73 \%)$, objek wisata alam $(18,07 \%)$, dan objek wisata budaya (15,62\%) (Kementerian Pariwisata dan Badan Pusat Statistik , 2016).

Pertumbuhan wisatawan tersebut menunjukkan bahwa sektor pariwisata memiliki potensi yang besar di dalam mendukung perekonomian Indonesia. Maka dari itu, pemerintah Indonesia khususnya Kementerian Pariwisata melakukan berbagai usaha baik berupa kebijakan, program, maupun kegiatan untuk meningkatkan sektor pariwisata di Indonesia. Usaha-usaha tersebut berupa Penetapan 10 Destinasi Wisata, Sosialisasi Branding Pesona Indonesia, Bantuan Desa Wisata, Kelompok Sadar Wisata, dan lain-lain (Kementerian Pariwisata).

Selain upaya-upaya tersebut, motivasi wisatawan merupakan faktor penentu lainnya di dalam meningkatkan kunjungan wisatawan. Push and pull factor merupakan teori motivasi wisata yang sering digunakan oleh banyak peneliti. Push factors merujuk pada kekuatan yang mendorong individu untuk memutuskan melakukan perjalanan dari rumah, sedangkan pull factors secara bersamaan menarik individu menuju tempat tersebut (Khuong \& Ha, 2014). Selain itu, pendapat lainnya diutarakan oleh Sayangbatti dan Baiquni (2013) yang berpendapat bahwa terdapat dua faktor yang memengaruhi keputusan terakhir wisatawan untuk melakukan kunjungan ke suatu destinasi wisata yaitu 1) faktor internal, yaitu faktor yang berasal dari diri wisatawan; dan 2) faktor eksternal, yaitu faktor yang berasal dari luar diri wisatawan. Dengan demikian, dapat diartikan bahwa push factor merupakan faktor internal dan pull faktor merupakan faktor eksternal.

Penelitian-penelitian tentang wisata lokal (Indonesia), umumnya membahas tentang faktor internal/motivasi (Sayangbatti \& Baiquni, 2013; Kusuma \& Suryasih, 2016), faktor 
eksternal/potensi/daya tarik tempat wisata (Sayangbatti \& Baiquni, 2013; Devy \& Soemanto, 2017), serta hubungan antara keduanya (Sayangbatti \& Baiquni, 2013).

Penelitian-penelitian tentang kepariwisataan manca-negara terdahulu juga cenderung memberikan perhatian pada motivasi/ push factor (Mohammad \& Som, 2010; Ambrož \& Ovsenik, 2011; Mahika, 2011; Vuuren \& Slabbert, 2011; Khuong \& Ha, 2014; Rid, Ezeuduji, \& Pröbstl-Haider, 2014; Assiouras, Skourtis, Koniordos, \& Giannopoulos, 2014; Sung, Chang, \& Sung, 2015; Song \& Bae, 2018), daya tarik wisata/pull factor (Khuong \& Ha, 2014; Assiouras, Skourtis, Koniordos, \& Giannopoulos, 2014; Sung, Chang, \& Sung, 2015), pengaruh push factor dan pull factor pada kepuasan/keinginan untuk berkunjung kembali/respon wisatawan lainnya (Khuong \& Ha, 2014), serta pengkategorian tipe wisatawan berdasarkan motivasi/lokasi (Rid, Ezeuduji, \& Pröbstl-Haider, 2014; Poria, Butler, \& Airey, 2003; Assiouras, Skourtis, Koniordos, \& Giannopoulos, 2014; Sung, Chang, \& Sung, 2015; Song \& Bae, 2018).

Di dalam upaya pengembangan pariwisata ke depannya, maka perlu adanya pendekatan pengembangan berdasarkan tipe wisatawan. Penelitian-penelitian terkait tipe wisatawan banyak dilakukan berdasarkan pada jenis kelamin, umur, dan etnis. Sedangkan penelitian ini bertujuan untuk melihat tipe wisatawan berdasarkan korelasi antara motivasi dan kegiatan di tempat wisata. Penelitian ini melakukan pendekatan penentuan tipe wisatawan berdasarkan korelasi antara faktor internal dan faktor eksternal, dimana faktor internal diwakili oleh motivasi wisatawan dan faktor eksternal diwakili oleh kegiatan di tempat wisata. Penelitian ini juga akan membahas motivasi wisata dan kegiatan wisata menurut responden di Indonesia.

\section{METODE PENELITIAN}

Metode yang digunakan dalam penelitian ini adalah mixed methods (kualitatifkuantitatif). Mixed methods bertujuan untuk menetralisasi bias yang terjadi jika hanya menggunakan satu metode saja (Creswell, 2003). Strategi yang digunakan di dalam penelitian ini adalah sekuensial prosedur. Sekuensial prosedur bertujuan untuk mengelaborasi atau memperkaya temuan dari satu metode dengan menggunakan metode lainnya (Creswell, 2003).

Pada penelitian ini metode yang pertama digunakan adalah metode kualitatif Grounded Theory (Creswell, 2006) dan kemudian menggunakan metode kuantitatif Correlational Research (Groat \& Wang, 2002). Metode kualitatif menjadi metode pertama yang digunakan karena metode ini bertujuan untuk mengeksplorasi dan memahami makna dari suatu fenomena serta membangun pemahaman berdasarkan individu atau kelompok tersebut (Creswell, 2003), sehingga peneliti mendapatkan faktor atau variabel dari pemahaman responden. Setelah mendapatkan berbagai faktor atau variabel dari responden, kemudian dilanjutkan dengan metode kuantitatif yang bertujuan untuk mengetahui faktor atau variabel yang mempengaruhi responden (Creswell, 2003).

\section{Metode Pengumpulan Data}

Pengumpulan data pada penelitian ini dibagi menjadi dua, yaitu pengumpulan data sekunder dan data primer. Data sekunder adalah data yang berasal dari penelitian lain atau sumber lainnya yang tidak dilakukan oleh peneliti, misalnya dari biro statistik, lembaga penelitian, atau publikasi lainnya (Marzuki, 2001). Penelitian ini melakukan pengumpulan data sekunder untuk mendapatkan data/kajian terkait motivasi wisata, kegiatan di tempat wisata, dan tipe wisatawan. Data sekunder tersebut berasal dari publikasi ilmiah seperti buku, jurnal, dan/atau artikel. Sedangkan, pengumpulan data primer menggunakan metode survei dalam bentuk kuesioner daring (online). Kuesioner daring dipilih karena dapat 
mempermudah peneliti di dalam mengakses masyarakat yang berada di berbagai daerah di Indonesia serta efektif dan efisien dari segi waktu.

Data dikumpulkan menggunakan nonprobability sampling, sehingga hasil yang didapat hanya menggambarkan kesimpulan dari kelompok responden (Creswell, 2012). Pendekatan yang digunakan adalah convenience sampling. Pada convenience sampling, peneliti memilih responden karena mereka bersedia menjadi responden (Creswell, 2012). Peneliti memilih untuk menyebarkan kuesioner daring ke grup peneliti yang berada pada akun sosial media berupa aplikasi Line. Maka dari itu, kelompok responden berasal dari rekan-rekan peneliti yang berada di dalam grup Line tersebut.

Fase pertama merupakan eksplorasi kualitatif terhadap motivasi dan kegiatan wisata. Kuesioner daring berisi pertanyaan yang disusun secara terbuka (open-ended) dengan tujuan untuk menggali informasi terkait motivasi dan kegiatan responden dalam berwisata. Pengambilan data melalui kuesioner daring dilakukan mulai dari 29 Agustus 2017 sampai dengan 03 September 2017, dengan total responden yang diperoleh sebanyak 139 orang. Proporsi responden adalah perempuan 55,4\% (77 orang) dan laki-laki 44,6\% (62 orang). Kemudian, usia responden beragam mulai dari yang termuda berusia 19 tahun hingga yang tertua berusia 43 tahun. Selain itu, responden berasal dari beragam pulau di Indonesia, yaitu Pulau Bali (2 orang), Pulau Jawa (75 orang), Pulau Sulawesi (2 orang), dan Pulau Sumatera (60 orang).

Data yang telah dikumpulkan kemudian dianalisis menggunakan analisis isi. Hasil analisis menunjukkan bahwa terdapat delapan belas (18) variabel atau kata kunci yang mewakili motivasi responden dalam melakukan wisata. Variabel atau kata kunci tersebut adalah "menghilangkan penat", "menyegarkan jasmani/kesehatan", "relaksasi", "bersantai", "bersenang-senang", "liburan", "momen interaksi", "menambah pengetahuan", "pengalaman baru", "tempat menarik", "menikmati pemandangan", "fotografi", "hobi", "kuliner", "mencari inspirasi”, "tafakur (merenung)", "menyegarkan rohani”, dan "mencari ketenangan".

Selanjutnya, hasil analisis menunjukkan bahwa terdapat dua belas (12) variabel atau kata kunci yang mewakili kegiatan responden di tempat wisata. Variabel atau kata kunci tersebut adalah "fotografi dan/atau videografi", "kuliner", "belanja", "kemah", "mencari informasi”, "eksplorasi”, "piknik (bersantai)", "mendaki”, "berenang”, "bersepeda”, "rafting", dan "snorkling dan/atau diving".

Variabel atau kata kunci yang berasal dari pendekatan kualitatif kemudian digunakan pada fase kedua dengan pendekatan kuantitatif. Sebagai tambahan, tiga (3) variabel atau kata kunci motivasi ditambah berdasarkan tinjauan teori, yaitu "olahraga", "kepentingan bisnis", dan "kepentingan pendidikan". Kuesioner daring berisi pertanyaan yang disusun secara tertutup (close-ended) berdasarkan variabel atau kata kunci. Pengambilan data kedua melalui kuesioner daring dilakukan mulai dari 24 Oktober 2017 sampai dengan 28 Oktober 2017, dengan total responden yang diperoleh sebanyak 131 orang. Proporsi responden adalah perempuan $61,1 \%$ (80 orang) dan laki-laki 38,9\% (51 orang). Kemudian, usia responden beragam mulai dari yang termuda berusia 19 tahun hingga yang tertua berusia 49 tahun. Selain itu, responden berasal dari beragam pulau di Indonesia, yaitu Pulau Jawa (85 orang), Pulau Kalimantan (2 orang), Pulau NTB (1 orang), dan Pulau Sumatera (43 orang).

Pertanyaan tertutup yang ditanyakan kepada responden disusun menggunakan jawaban dengan Skala Likert. Jawaban yang diberikan melalui metode ini merepresentasikan tingkatan kesetujuan responden terhadap motivasi mereka ketika berwisata serta kegiatan yang mereka lakukan di tempat wisata. Setiap pertanyaan memiliki jawaban dengan skala 1 sampai 5. Skala tersebut memiliki dua sisi kutub yang saling berlawanan. Skala 1 menunjukkan sangat tidak setuju, sedangkan skala 5 menunjukkan sangat setuju. Tabel 1 menunjukkan contoh pertanyaan dari kuesioner daring terkait motivasi wisata dan kegiatan di tempat wisata. 
Tabel 1. Contoh Pertanyaan Menggunakan Skala Likert

\begin{tabular}{|c|c|c|c|c|c|c|c|c|}
\hline \multicolumn{2}{|l|}{ Kategori } & \multicolumn{7}{|c|}{ Contoh Pertanyaan } \\
\hline \multirow{2}{*}{$\begin{array}{l}\text { Motivasi } \\
\text { Berwista }\end{array}$} & \multicolumn{8}{|c|}{ Berwisata membantu saya untuk menghilangkan penat (refreshing) } \\
\hline & $\begin{array}{l}\text { Sangat } \\
\text { Setuju }\end{array}$ & Tidak & 1 & 2 & 3 & 4 & 5 & $\begin{array}{l}\text { Sangat } \\
\text { Setuju }\end{array}$ \\
\hline \multirow{2}{*}{\begin{tabular}{ll}
\multicolumn{2}{l}{ Kegiatan } \\
di $\quad$ Tempat \\
Wisata
\end{tabular}} & \multicolumn{8}{|c|}{ Saya melakukan kegiatan fotografi dan/atau videografi } \\
\hline & $\begin{array}{l}\text { Sangat } \\
\text { Setuju }\end{array}$ & Tidak & 1 & 2 & 3 & 4 & 5 & $\begin{array}{l}\text { Sangat } \\
\text { Setuju }\end{array}$ \\
\hline
\end{tabular}

Sumber: Hasil Analisis, 2018

\section{Metode Analisis Data}

Metode analisis yang digunakan pada penelitian ini adalah principal component analysis (PCA) dan analisis faktor, serta analisis korelasi multivariat. Principal component analysis (PCA) dapat digunakan untuk mengidentifikasi dimensi yang mendasari penjelasan tanggapan (response) terhadap kuesioner (Bryant \& Yarnold, 2001). Tujuan dari PCA adalah mengidentifikasi variabel baru yang dapat mewakili beberapa variabel operasional, yang disebut dengan principal components (Bryant \& Yarnold, 2001). Principal components tersebut bisa menjelaskan semua atau hampir semua dari total variabel yang beragam (Bryant \& Yarnold, 2001). Selanjutnya dilakukan analisis faktor untuk menentukan faktorfaktor dari principal components.

Exploratory factor analysis (EFA) find factors that maximize the amount of the common variance that is explained (Bryant \& Yarnold, 2001).

Analisis terakhir adalah analisis korelasi multivariat yang dibutuhkan untuk menunjukkan hubungan korelasional antar variabel (Licht, 2001).

\section{HASIL DAN PEMBAHASAN}

Kajian terkait motivasi wisata merupakan instrumen yang kuat bagi praktisi di bidang kepariwisataan (Mahika, 2011). Setiap wisatawan yang berkunjung ke tempat wisata tentunya memiliki motivasi masing-masing. Selain itu, motivasi juga menjadi penggerak utama untuk mempelajari perilaku dari seseorang (Khuong \& Ha, 2014). Pendapat lain dari Kanfer (1990) yang menyatakan bahwa motivasi adalah perilaku yang terjadi akibat adanya dorongan baik dari dalam maupun luar diri seseorang, dan bukan berdasarkan tuntutan lingkungan yang memaksa perilaku tersebut terjadi.

Joseph pada bukunya yang berjudul Tourism Priciples, Policies \& Practices menjelaskan bahwa terdapat empat motivasi di dalam berwisata, yaitu motivasi fisik, motivasi interpersonal, motivasi budaya, serta motivasi status dan martabat. Setiap motivasi tersebut dijabarkan sebagai berikut (Joseph, 2013): 1) motivasi fisik, berkaitan dengan relaksasi, aktivitas olahraga, dan kesehatan; 2) motivasi interpersonal, berkaitan dengan berkunjung ke tempat keluarga atau teman serta keluar dari rutinitas sehari-hari; 3) motivasi budaya, berkaitan dengan mengunjungi suatu tempat untuk mengetahui tradisi, gaya hidup, tempat, etnik, dan lain-lain di tempat tersebut; dan 4) motivasi status dan martabat, berkaitan dengan menghargai diri sendiri ataupun pengembangan diri, termasuk juga kepentingan bisnis, pendidikan, dan hobi.

Crompton (1979) memberikan pendapat lain bahwa terdapat tujuh kategori dari motivasi wisata, yaitu: 1) kebaruan, berhubungan dengan mencari pengalaman baru; 2) sosialisasi, berhubungan dengan berinteraksi dengan suatu kelompok; 3) martabat, berhubungan dengan keinginan untuk mendapatkan martabat tinggi di mata orang; 4) relaksasi, berhubungan dengan menghilangkan penat baik mental maupun fisik; 5) pendidikan, berhubungan dengan mendapatkan pengetahuan dan memperluas wawasan; 6) 
kekeluargaan, berhubungan dengan meningkatkan hubungan dengan keluarga; serta 7) regresi, berhubungan dengan melakukan hal yang memicu kenangan masa kecil.

Motivasi wisata lainnya didapat dari pemerintah Hong Kong yang membedakan motivasi menjadi delapan (Education Bureau of Hong Kong, 2013), yaitu: 1) liburan, berhubungan dengan relaksasi dan melihat-lihat; 2) bisnis, berhubungan dengan kepentingan bisnis; 3) budaya, berhubungan dengan penambahan wawasan terkait tempat wisata; 4) ekowisata, berhubungan dengan menikmati alam; 5) belajar, berhubungan dengan belajar dikarenakan kepentingan akademik; 6) keagamaan, berhubungan dengan perjalanan religi; 7) kesehatan, berhubungan dengan keperluan pengobatan; serta 8) mengunjungi teman dan kerabat.

Banyak penelitian yang telah dilakukan terkait dengan motivasi wisata dengan studi kasus di berbagai negara di dunia, seperti Jordan, Slovenia, South Africa, Gambia, Greece, dan Taiwan. Berdasarkan penelitian yang dilakukan oleh Mohammad and Som (2010) motivasi wisatawan mancanegara dalam mengunjungi Jordan (studi kasus: Kota Amman dan Petra) dibagi menjadi dua yaitu push factor dan pull factor. Push factors berupa fulfilling prestige, enhancing relation, seeking relaxation, enhancing social circle, sightseeing variety, fulfilling spiritual needs, escaping from daily routine, dan gaining knowledge. Pull factors berupa events and activities, easy access and affordable, history and culture, variety seeking, adventure, natural resources, heritage sites, dan sightseeing variety.

Selain itu, terdapat pula penelitian lain yang menunjukkan secara spesifik motif spiritual yang melandasi wisatawan berkunjung ke Portozo, Slovenia yang dilakukan oleh Ambroz dan Ovsenik (2011). Kelima motivasi tersebut adalah spiritual experience, relationship, self-esteem and development, value of work, dan quality of tourism services. Penelitian di Kwazulu-Natal, South Africa menunjukkan bahwa terdapat empat motivasi wisata, yaitu resting and relaxation, enriching and learning experiences, participation in recreational activities, dan personal values and social experiences (Vuuren \& Slabbert, 2011).

Motivasi wisatwan yang berkunjung ke pedesaan di Gambia berupa heritage \& nature motive, the authentic rural experience motive, the learning motive, dan the sun \& beach motive (Rid, Ezeuduji, \& Pröbstl-Haider, 2014). Selain itu, ada pula motivasi wisatawan Asia Timur mengunjungi Greece berdasarkan penelitian Assiouras, Skourtis, Koniordos, dan Giannopoulos (2014) dilihat dari push factor dan pull factor. Push factors berupa Knowledge, Ego-enhancement, Escape \& Relaxation, dan Novelty dan pull factors berupa Leisure, shopping \& safety, Variety and cost, Culture \& heritage, dan Travel arrangements \& facilities.

Penelitian dengan lokasi di Taiwan menunjukkan bahwa motivasi wisata dibagi menjadi push factor dan pull factor. Push factor berupa enlightenment and reputation; unusual and affection; freedom; interpersonal communication and sharing; dan family and friends relationship sedangkan pull factor berupa attitude and quality of service; cost, shopping, and tasting; diverse attraction; cultural connections; sport facilities, wildlife, and events; dan accessibility (Sung, Chang, \& Sung, 2015).

\section{Kegiatan Wisata}

Motivasi yang berbeda akan menentukan jenis kegiatan yang berbeda pula. Kementerian Pariwisata RI (2016) mengkategorikan kegiatan wisata menjadi 9 kategori, yaitu 1) wisata bahari meliputi selancar, berjemur, parasailing, naik kapal pesiar, sailing/yachting, memancing (di laut), menyelam, dan snorkeling, 2) eko-wisata meliputi penelitian/pendidikan yang berhubungan dengan lingkungan, bersepeda gunung, safari \& bird watching, susur sungai, penyelamatan hewan langka, ecoriding, penjelajahan dan reli, bertani/ berkebun; 3) wisata petualangan meliputi berkemah, trekking/hiking/climbing, jelajah goa, berburu, rafting, kayak, river/lake cruise, bungee jumping, sky diving, 4) wisata sejarah/religi merupakan wisata warisan budaya/sejarah, keagamaan, dan wisata syariah, meliputi: penelitian/pendidikan yang berhubungan dengan kebudayaan, ziarah, 
mengunjungi tempat suci, museum, warisan budaya, keagamaan, memorial, jejak peradaban; 5) wisata kesenian \& kuliner meliputi pertunjukan cerita rakyat, teater, pertunjukan budaya pop, upacara tradisi, karnaval, seni tradisional, makan malam, membeli makanan lokal, mencicipi makanan unik; 6) wisata kota \& pedesaan meliputi belanja, mengunjungi teman atau kerabat, menikmati hiburan malam, tinggal di desa tradisional, mengunjungi pasar tradisional, wisata darmabakti, filantropis (dermawan) dan program tanggung jawab sosial perusahaan, fotografi and architectural visit, live-in program; 7) wisata MICE meliputi pertemuan dan forum bisnis, insentif, konferensi, ekshibisi pameran dagang, bisnis pertunjukan, konser, film; 8) wisata olahraga/kesehatan meliputi spa dan kebugaran, yoga dan meditasi, wisata medis dan kesehatan, berpatisipasi dalam acara olahraga internasional, menonton acara olahraga, pemusatan latihan, mengunjungi lokasi olahraga ekstrim, berpatisipasi dalam olahraga ekstrim, belajar dan latihan olahraga ekstrim; dan 9) objek wisata terintegrasi meliputi ecopark, recreation and outbound park, kebun binatang, kebun raya botani, taman bermain untuk remaja dan anak-anak, pensiunan/silver tourism, program pernikahan dan bulan madu, resort dan pulau di pinggir pantai, resort di pegunungan, dark tourism.

\section{Tipe Wisatawan}

Poria, Butler, dan Airey (2003) menyatakan bahwa wisatawan pada kasus wisata bersejarah dapat dibedakan menjadi empat tipe berdasarkan persepsinya, yaitu 1) Group I, tourist who are not aware of the heritage attributes of the site; 2) Goup II, tourist who are aware of the heritage attributes of the site, but are motivated by other attributes to visit the site, 3) Group III, tourist who are motivated by the heritage attributes of the site, but do not consider these attributes as part of their own heritage; dan 4) Group IV, tourist who are motivated by the heritage attributes of the site, and consider the site as part of their own heritage. Song dan Bae (2018) membagi motivasi menjadi tiga kelas yaitu core layer motive yang terdiri dari novelty, escape/relaxation, dan enhanced relationship; middle layer motive yang terdiri dari externally oriented (nature, host-site involvement dan sense of belonging) dan internally oriented (personal development dan self-actualization); dan outer layer motive yang terdiri dari autonom, isolation, nostalgia, romance, luxury, dan recognation.

Selain itu, terdapat beberapa penelitian tipe wisatawan dari beberapa negara seperti Gambia, Greece, dan Taiwan. Penelitian di Gambia untuk wisata pedesaan menunjukkan bahwa terdapat empat tipe wisatawan, yaitu heritage \& nature seekers, multi-experiences seekers, multi-experiences \& beach seekers, dan sun \& beach seekers (Rid, Ezeuduji, \& Pröbstl-Haider, 2014). Penelitian lainnya dengan studi kasus di Greece menghasilkan tiga tipe wisatwan, yaitu novelty seeker, want-it-all, dan lowly motivated (Assiouras, Skourtis, Koniordos, \& Giannopoulos, 2014). Penelitian yang dilakukan oleh Sung, Chang, dan Sung (2015) di Taiwan menghasilkan lima tipe, yaitu knowledge seekers, expenditure seekers, relaxation/relation seekers, novelty/experience seekers, dan sport/service seekers.

Tabel 2. Tipe Wisatawan Menurut Literatur 


\begin{tabular}{|c|c|c|c|c|c|c|}
\hline & $\begin{array}{lr}\text { Poria, } & \text { Butler, } \\
\text { dan } & \text { Airy } \\
(2003) & \end{array}$ & $\begin{array}{l}\text { Song da } \\
(2018)\end{array}$ & In Bae & $\begin{array}{l}\text { Rid, Ezeuduji, } \\
\& \quad \text { Pröbstl- } \\
\text { Haider (2014) }\end{array}$ & $\begin{array}{l}\text { Assiouras, } \\
\text { Skourtis, } \\
\text { Koniordos, \& } \\
\text { Giannopoulos } \\
(2014)\end{array}$ & $\begin{array}{l}\text { Sung, Chang, dan } \\
\text { Sung (2015) }\end{array}$ \\
\hline $\begin{array}{l}\text { Type of } \\
\text { Tourist based } \\
\text { on }\end{array}$ & $\begin{array}{l}\text { Heritage } \\
\text { Tourism }\end{array}$ & \multicolumn{2}{|c|}{ Motivation } & Motivation & Motivation & Motivation \\
\hline \multicolumn{2}{|l|}{ Case Study } & \multirow[b]{2}{*}{$\begin{array}{l}\text { Core } \\
\text { Motive }\end{array}$} & \multirow[b]{2}{*}{ Layer } & \multirow{2}{*}{$\begin{array}{l}\text { Gambia } \\
\text { Heritage and } \\
\text { Nature } \\
\text { Seekers }\end{array}$} & Greece & Taiwan \\
\hline \multirow[t]{4}{*}{$\begin{array}{l}\text { Type } \\
\text { Tourist }\end{array}$} & Group I & & & & $\begin{array}{l}\text { Novelty } \\
\text { Seeker }\end{array}$ & Knowledge Seekers \\
\hline & Goup II & $\begin{array}{l}\text { Middle } \\
\text { Motive }\end{array}$ & Layer & $\begin{array}{l}\text { Multi- } \\
\text { experiences } \\
\text { Seekers }\end{array}$ & Want-it-all & $\begin{array}{l}\text { Expenditure } \\
\text { Seekers }\end{array}$ \\
\hline & Group III & $\begin{array}{l}\text { Outer } \\
\text { Motive }\end{array}$ & Layer & $\begin{array}{l}\text { Multi- } \\
\text { experiences \& } \\
\text { Beach Seekers }\end{array}$ & $\begin{array}{l}\text { Lowly } \\
\text { Motivated }\end{array}$ & $\begin{array}{l}\text { Relaxation/relation } \\
\text { Seekers }\end{array}$ \\
\hline & Group IV & & & $\begin{array}{l}\text { Sun \& Beach } \\
\text { Seekers }\end{array}$ & & $\begin{array}{l}\text { Novelty/experience } \\
\text { Seekers } \\
\text { Sport/service } \\
\text { Seekers }\end{array}$ \\
\hline
\end{tabular}

Sumber: Hasil Analisis, 2018

Keterangan:

1) Group I, tourist who are not aware of the heritage attributes of the site; 2) Goup II, tourist who are aware of the heritage attributes of the site, but are motivated by other attributes to visit the site; 3) Group III, tourist who are motivated by the heritage attributes of the site, but do not consider these attributes as part of their own heritage; dan 4) Group IV, tourist who are motivated by the heritage attributes of the site, and consider the site as part of their own heritage

PCA digunakan untuk menentukan jumlah principal components (eigenvectors) melalui eigenvalue atau dikenal dengan stopping rule. Kaiser (1960, dalam Bryant \& Yarnold, 1995) menyatakan bahwa jumlah eigenvectors ditentukan berdasarkan nilai eigenvalue yang bernilai minimal 1. Stevens (1986, dalam Bryant \& Yarnold, 1995) menyatakan bahwa metode stopping rule Kaiser dapat digunakan jika variabel kurang dari 30 variabel. Peneliti mempertimbangkan untuk menentukan eigenvactors menggunakan stopping rule dari Kaiser karena variabel kurang dari 30.

Tabel 1. Variabel Laten dari Hasil Analisis Faktor dengan Varimax Rotation dari 6 Principal Components

\begin{tabular}{|c|c|c|c|c|c|c|}
\hline Variabel & Kontemplasi & $\begin{array}{l}\text { Eksplorasi- } \\
\text { Sosial }\end{array}$ & Restoratif & Kuliner & Kesempatan & Kebaruan \\
\hline $\begin{array}{l}\text { Menyegarkan } \\
\text { Rohani }\end{array}$ & 0,88 & 0,11 & 0,13 & 0,02 & 0,15 & 0,04 \\
\hline Ketenangan & 0,85 & 0,11 & 0,18 & 0,06 & $-0,02$ & 0,08 \\
\hline Merenung & 0,82 & 0,04 & 0,02 & 0,09 & 0,26 & 0,15 \\
\hline Inspirasi & 0,62 & 0,11 & 0,08 & 0,21 & 0,30 & 0,38 \\
\hline Menarik & 0,10 & 0,80 & 0,05 & 0,09 & $-0,04$ & 0,18 \\
\hline Pemandangan & 0,24 & 0,75 & 0,23 & $-0,04$ & $-0,13$ & 0,10 \\
\hline $\begin{array}{l}\text { Momen } \\
\text { Interaksi }\end{array}$ & 0,07 & 0,66 & 0,01 & 0,07 & 0,13 & 0,36 \\
\hline Liburan & $-0,03$ & 0,65 & $-0,05$ & 0,51 & 0,12 & $-0,09$ \\
\hline $\begin{array}{l}\text { Bersenang- } \\
\text { senang }\end{array}$ & $-0,11$ & 0,57 & 0,16 & 0,54 & 0,11 & $-0,23$ \\
\hline Relaksasi & 0,08 & $-0,03$ & 0,75 & 0,09 & 0,17 & 0,17 \\
\hline
\end{tabular}




\begin{tabular}{lcccccc}
\hline Variabel & Kontemplasi & $\begin{array}{l}\text { Eksplorasi- } \\
\text { Sosial }\end{array}$ & Restoratif & Kuliner & Kesempatan & Kebaruan \\
\hline Menyegarkan & 0,34 & 0,38 & 0,63 & $-0,03$ & 0,03 & $-0,14$ \\
Jasmani & $-0,05$ & 0,02 & 0,62 & 0,40 & 0,03 & 0,15 \\
Fotografi & 0,20 & 0,09 & 0,59 & $-0,25$ & 0,27 & 0,29 \\
Olahraga & 0,19 & 0,44 & 0,48 & 0,35 & $-0,07$ & $-0,29$ \\
Refreshing & 0,37 & 0,30 & 0,43 & 0,25 & $-0,03$ & 0,29 \\
Hobi & 0,13 & 0,10 & 0,02 & 0,74 & 0,16 & 0,30 \\
Kuliner & 0,40 & 0,13 & 0,25 & 0,60 & $-0,10$ & 0,01 \\
Bersantai & 0,09 & $-0,14$ & 0,26 & 0,02 & 0,79 & $-0,10$ \\
Bisnis & 0,32 & 0,18 & 0,02 & 0,13 & 0,79 & 0,13 \\
Pendidikan & 0,22 & 0,27 & 0,21 & 0,13 & 0,07 & 0,69 \\
Pengetahuan & 0,37 & 0,09 & 0,34 & 0,05 & $-0,24$ & 0,51 \\
Pengalaman & & & & & & \\
\hline
\end{tabular}

Sumber: Hasil Analisis, 2018

Berdasarkan hasil dari PCA, motivasi berwisata memiliki 6 principal components dengan eigenvalue lebih dari 1 (persentase kumulatif sebesar 67,99\%) yang dapat menggambarkan 18 variabel terukur. Tabel 3 menunjukkan 6 variabel laten yang terbentuk berdasarkan analisis faktor, yang diberi nama "kontemplasi”, "eksplorasi-sosial", "restoratif", "kuliner", "kesempatan", dan "kebaruan".

Motivasi berwisata dapat diartikan sebagai faktor yang membuat seseorang ingin melakukan wisata (Joseph, 2013). Motivasi menurut beberapa literatur dapat disimpulkan seperti pada tabel 4 . Terdapat lima motivasi pada penelitian yang memiliki kesamaan dengan motivasi pada penelitian terdahulu. Pertama, motivasi restoratif yang berkaitan dengan relaksasi, kesehatan, dan keluar dari rutinitas sehari-hari dengan tujuan untuk mencari suasana baru. Kedua, eksplorasi dan sosial yang berisi kelompok variabel eksplorasi dan interaksi sosial. Dimensi ini menunjukkan bahwa interaksi sosial di tempat wisata cenderung dilakukan di tempat yang memiliki pemandangan yang menarik.

Ketiga, kebaruan yang berkaitan dengan menambah ilmu, pengetahuan, dan pengalaman baru akan suatu tempat dan/atau budaya. Keempat, kesempatan yang bertujuan untuk melakukan wisata karena kesempatan bisnis atau pendidikan. Kelima, kontemplasi yang berkiatan dengan memenuhi kebutuhan spiritual atau berkaitan dengan religi wisatawan. 
Tipe Wisatawan berdasarkan Korelasi Motivasi dan Kegiatan di Tempat Wisata

323

Tabel 2. Perbandingan Motivasi Wisata dalam Literatur dan Hasil Penelitian

\begin{tabular}{|c|c|c|c|c|c|c|c|c|c|}
\hline $\begin{array}{l}\text { Crompton } \\
(1979)\end{array}$ & $\begin{array}{l}\text { Joseph } \\
\text { (2013) }\end{array}$ & $\begin{array}{l}\text { Edu- } \\
\text { cation } \\
\text { Bureau } \\
\text { of Hong } \\
\text { Kong } \\
(2013)\end{array}$ & $\begin{array}{l}\text { Mohammad } \\
\text { and Som } \\
(2015)\end{array}$ & $\begin{array}{l}\text { Ambroz dan } \\
\text { Ovsenik } \\
(2011)\end{array}$ & $\begin{array}{l}\text { Vuuren and } \\
\text { Slabbert } \\
(2011)\end{array}$ & $\begin{array}{l}\text { Rid, } \\
\text { Ezeuduji, } \\
\text { and } \\
\text { Pröbstl- } \\
\text { Haider } \\
(2014)\end{array}$ & $\begin{array}{l}\text { Giannopou } \\
\text { los (2014) }\end{array}$ & $\begin{array}{l}\text { Sung, } \quad \text { Chang, } \\
\text { and } \\
(2015)\end{array}$ & $\begin{array}{l}\text { Motivasi } \\
\text { (Hasil } \\
\text { Penelitian) }\end{array}$ \\
\hline \multirow[b]{2}{*}{ Relaxation } & \multirow[b]{2}{*}{ Physic } & Holiday & $\begin{array}{l}\text { Seeking } \\
\text { Relaxation }\end{array}$ & & \multirow{2}{*}{$\begin{array}{l}\text { Resting and } \\
\text { relaxation }\end{array}$} & & \multirow{2}{*}{$\begin{array}{l}\text { Escape and } \\
\text { Relaxation }\end{array}$} & \multirow[b]{2}{*}{ Freedom } & \multirow[b]{2}{*}{ Restoratif } \\
\hline & & Health & $\begin{array}{l}\text { Escaping } \\
\text { from daily } \\
\text { routine }\end{array}$ & & & & & & \\
\hline Social & \multirow{2}{*}{$\begin{array}{l}\text { Interper } \\
\text { sonal }\end{array}$} & \multirow{2}{*}{$\begin{array}{l}\text { Visiting } \\
\text { friends } \\
\text { and } \\
\text { relatives }\end{array}$} & $\begin{array}{l}\text { Enhancing } \\
\text { Relation }\end{array}$ & \multirow{2}{*}{ Relationship } & & & & $\begin{array}{l}\text { Interpersonal } \\
\text { communication } \\
\text { and sharing }\end{array}$ & \multirow{2}{*}{$\begin{array}{l}\text { Eksplorasi- } \\
\text { Sosial }\end{array}$} \\
\hline Family & & & $\begin{array}{l}\text { Enhancing } \\
\text { Social } \\
\text { Circle } \\
\end{array}$ & & & & & $\begin{array}{l}\text { Family and } \\
\text { friends } \\
\text { relationship }\end{array}$ & \\
\hline Novelty & \multirow{2}{*}{ Culture } & \multirow{2}{*}{ Culture } & $\begin{array}{l}\text { Sightseeing } \\
\text { variety }\end{array}$ & & \multirow{2}{*}{$\begin{array}{l}\text { Enriching } \\
\text { and learning } \\
\text { experiences }\end{array}$} & \multirow{2}{*}{$\begin{array}{l}\text { Learning } \\
\text { motive }\end{array}$} & Knowledge & \multirow{2}{*}{$\begin{array}{l}\text { Unusual } \\
\text { affection }\end{array}$} & \multirow{2}{*}{ Kebaruan } \\
\hline \multirow[t]{7}{*}{ Education } & & & $\begin{array}{l}\text { Gaining } \\
\text { knowledge }\end{array}$ & & & & Novelty & & \\
\hline & & Business & & & $\begin{array}{l}\text { Participation } \\
\text { in }\end{array}$ & & & & \\
\hline & & Study & & & activities & & & & \\
\hline & & \multirow{4}{*}{ Religion } & \multirow{4}{*}{$\begin{array}{l}\text { Fulfilling } \\
\text { spiritual } \\
\text { needs }\end{array}$} & $\begin{array}{l}\text { Spiritual } \\
\text { experience }\end{array}$ & \multirow{3}{*}{$\begin{array}{l}\text { Personal } \\
\text { values and } \\
\text { social } \\
\text { experiences }\end{array}$} & & \multirow{3}{*}{$\begin{array}{l}\text { Ego- } \\
\text { enhanceme } \\
\text { nt }\end{array}$} & & \multirow{3}{*}{ Kontemplasi } \\
\hline & & & & $\begin{array}{l}\text { Self-esteem } \\
\text { and } \\
\text { development }\end{array}$ & & & & & \\
\hline & & & & $\begin{array}{l}\begin{array}{l}\text { Value } \\
\text { work }\end{array} \\
\end{array}$ & & & & & \\
\hline & & & & & & & & & Kuliner \\
\hline \multirow[t]{2}{*}{ Prestige } & $\begin{array}{l}\text { Status } \\
\text { and } \\
\text { Prestige }\end{array}$ & & $\begin{array}{l}\text { Fulfilling } \\
\text { Prestige }\end{array}$ & & & & & $\begin{array}{l}\text { Enlightenment } \\
\text { and reputation }\end{array}$ & \\
\hline & & $\begin{array}{l}\text { Eco- } \\
\text { tourism }\end{array}$ & & & & & & & \\
\hline Regression & & & & & & & & & \\
\hline
\end{tabular}

Sumber: Hasil Analisis, 2018

Selain persamaan, terdapat pula perbedaan motivasi yang ditemukan pada penelitian ini dan tidak ditemukan pada penelitian sebelumnya, yaitu kuliner. Motivasi kuliner berkaitan dengan kuliner dan bersantai. Kemudian, terdapat tiga motivasi yang tidak ditemukan pada penelitian ini namun ditemukan pada penelitan sebelumnya, yaitu prestige(Crompton, 1979; Joseph, 2013; Mohammad and Som, 2015; Sung, Chang, and Sung, 2015), eco-tourism (Education Bureau of Hong Kong, 2013), dan regression (Crompton, 1979).

Tabel 3. Variabel Laten dari Hasil Analisis Faktor dengan Varimax Rotation dari 4 Principal

Components

\begin{tabular}{llllll}
\hline \multicolumn{1}{c}{ Variabel } & Kegiatan Fisik & & Kognitif & Afektif & Petualangan \\
\hline Snorkling/diving & 0,83 & 0,15 & 0,10 & $-0,01$ \\
Bersepeda & 0,81 & 0,13 & 0,07 & 0,18 \\
Berenang & 0,79 & 0,01 & 0,13 & $-0,07$ \\
Rafting & 0,75 & 0,24 & $-0,01$ & 0,19 \\
Informasi & 0,33 & 0,78 & $-0,03$ & 0,04 \\
Eksplorasi & 0,12 & 0,77 & 0,04 & 0,22 \\
Piknik & 0,02 & 0,69 & 0,22 & 0,22 \\
\hline
\end{tabular}




\begin{tabular}{|c|c|c|c|c|}
\hline Variabel & Kegiatan Fisik & Kognitif & Afektif & Petualangan \\
\hline Kuliner & 0,08 & 0,22 & 0,83 & $-0,17$ \\
\hline Foto/videografi & $-0,03$ & $-0,14$ & 0,73 & 0,35 \\
\hline Belanja & 0,25 & 0,14 & 0,71 & $-0,23$ \\
\hline Kemah & 0,16 & 0,20 & 0,00 & 0,84 \\
\hline Mendaki & 0,05 & 0,24 & $-0,10$ & 0,79 \\
\hline
\end{tabular}

Sumber: Hasil Analisis, 2018

Berdasarkan hasil dari PCA, kegiatan di tempat wisata memiliki 4 principal components dengan eigenvalue lebih dari 1 (persentase kumulatif sebesar 68,53\%) yang dapat menggambarkan 12 variabel terukur. Tabel 5 menunjukkan 4 variabel laten yang terbentuk berdasarkan analisis faktor, yang diberi nama "kegiatan fisik", "kognitif", "afektif", dan "petualangan".

Hasil dari analisis faktor kegiatan di tempat wisata memiliki kesamaan dengan literatur. Terdapat 9 bentuk kegiatan menurut Kementerian Pariwisata RI (2016) yaitu, wisata bahari, eko-wisata, wisata petualangan, wisata sejarah/religi, wisata kesenian \& kuliner, wisata kota \& pedesaan, wisata MICE, wisata olahraga/kesehatan, dan objek wisata terintegrasi.

Wisata bahari memiliki kesamaan dengan kegiatan fisik. Kegiatan ini meliputi snorkling/diving, bersepeda, berenang, dan rafting. Kemudian, wisata sejarah/religi memiliki kesamaan dengan kegiatan kognitif. Kegiatan tersebut berupa mencari informasi, eksplorasi tempat wisata, dan piknik.

Wisata kesenian \& kuliner serta wisata kota \& pedesaan memiliki kesamaan dengan kegiatan afektif. Kegiatan ini berkaitan dengan mencicipi makanan unik yang ada di tempat wisata, foto/videografi, dan belanja. Terakhir adalah wisata petualangan memiliki kesamaan dengan kegiatan menikmati alam. Kegiatan yang dilakukan berupa kemah dan mendaki.

Terdapat 4 bentuk kegiatan menurut Kementerian Pariwisata RI (2016) yang tidak ditemukan di dalam penelitian ini, yaitu eko-wisata, wisata MICE, wisata olahraga/kesehatan, dan objek wisata terintegrasi.

Tabel 4. Analisis Korelasi Multivariat antara Motivasi Wisata terhadap Kegiatan di Tempat Wisata

\begin{tabular}{lllll} 
& & & \\
Kotivasi & & & & \\
\hline Kontemplasi & 0,06 & $0,19 *$ & $-0,01$ & $0,25 * *$ \\
Eksplorasi-Sosial & 0,02 & $0,39 * * *$ & 0,02 & 0,09 \\
Restoratif & $0,19 *$ & $-0,02$ & $0,18 *$ & $0,49 * * *$ \\
Kuliner & $-0,03$ & 0,13 & $0,55 * * *$ & $-0,08$ \\
Kesempatan & 0,14 & 0,11 & 0,02 & 0,06 \\
Kebaruan & 0,10 & 0,14 & 0,17 & 0,17 \\
\hline Keterangan: $* \mathrm{p}<0,05 * * \mathrm{p}<0,01 * * * \mathrm{p}<0,0001$ & &
\end{tabular}

Sumber: Hasil Analisis, 2018

Setelah mengetahui faktor-faktor dari motivasi wisata dan kegiatan wisata, maka selanjutnya penelitian ini melihat korelasi dari kedua variabel tersebut seperti ditunjukkan pada tabel 6. Hasil analisis menunjukan terdapat beberapa variabel yang memiliki korelasi yang signifikan. Nilai yang mendekati 1 mengindikasikan hubungan yang sangat sempurna. Berdasarkan hasil dari korelasi tersebut, maka didapat bahwa responden yang berwisata dengan motivasi eksplorasi-sosial akan cenderung memilih untuk melakukan kegiatankegiatan yang bersifat kognitif. Responden yang berwisata dengan motivasi kuliner akan 
cenderung memilih untuk melakukan kegiatan-kegiatan yang bersifat afektif. Sedangkan responden yang berwisata dengan motivasi restoratif akan cenderung memilih untuk melakukan kegiatan-kegiatan berupa petualangan.

Hubungan korelasi tersebut membentuk pola yang dapat menunjukkan tiga tipe wisatawan yaitu explorer, pleasure seeker, dan adventurer seperti pada tabel 7. Tipe pertama adalah explorer, wisatawan tipe ini pergi berwisata dengan motif eksplorasi dan sosial. Mereka berwisata karena tempat yang menarik, pemandangan yang indah, serta memanfaatkan waktu wisata sebagai momen interaksi, liburan, dan bersenang-senang bersama keluarga. Kegiatan yang dilakukan merupakan kegiatan kognitif, berupa mencari informasi dan eksplorasi dimana orang tua dapat menambahkan ilmu kepada anak-anaknya sambil berwisata. Selain itu, wisatawan explorer juga memilih untuk piknik, duduk bersama sambil bercerita.

Tabel 5. Tiga Tipe Wisatawan berdasarkan Motivasi dan Kegiatan

\begin{tabular}{lll}
\hline Wisatawan & \multicolumn{1}{c}{ Motivasi } & \multicolumn{1}{c}{ Kegiatan } \\
\hline Explorer & Eksplorasi-sosial & Kognitif \\
& - Tempat Wisata Menarik & - Mencari Informasi \\
& - Pemandangan Indah & - Eksplorasi Wisata \\
& - Momen Interaksi & - Piknik \\
& - Liburan & \\
& - Bersenang-senang & \\
\hline Pleasure Seeker & Kuliner & Afektif \\
& - Menikmati Kuliner & - Kuliner \\
& - Bersantai & - Foto/videografi \\
& & - Belanja \\
\hline Adventurer & Restoratif & Petualangan \\
& - Relaksasi & - Kemah \\
& - Menyegarkan Jasmani & - Mendaki \\
& - Fotografi & \\
& - Olahraga & \\
& - Refreshing & \\
& - Hobi & \\
\hline
\end{tabular}

Sumber: Hasil Analisis, 2018

Tipe kedua adalah pleasure seeker, wisatawan tipe ini pergi berwisata dengan motivasi kuliner. Mereka berwisata untuk menikmati kuliner dan bersantai. Kegiatan yang dilakukan merupakan kegiatan afektif yang cenderung untuk mencari kesenangan seperti kuliner, foto/videografi, dan belanja.

Tipe terakhir adalah adventurer, wisatawan tipe ini pergi berwisata dengan motivasi restoratif. Mereka berwisata untuk relaksasi, menyegarkan jasmani, fotografi, olahraga, refreshing, dan hobi. Kegiatan yang dilakukan merupakan kegiatan menikmati alam, berupa kemah dan mendaki.

\section{KESIMPULAN}

Perjalanan wisata di era sekarang telah menjadi kebutuhan masyarakat. Perjalanan wisata tersebut dilakukan karena adanya berbagai motivasi. Penelitian ini menemukan enam dimensi motivasi wisata yaitu kontemplasi, eksplorasi-sosial, restoratif, kuliner, kesempatan, dan kebaruan. Selain itu, juga ditemukan empat dimensi kegiatan wisata, yaitu kegiatan fisik, kognitif, afektif, dan petualangan.

Dari analisis korelasi antara enam dimensi motivasi wisata dan empat dimensi kegiatan wisata, terungkap nilai korelasi yang tinggi antara motivasi eksplorasi-sosial dan kegiatan kognitif, kuliner dan kegiatan afektif, dan motivasi restoratif dan kegiatan 
petualangan. Pola korelasi tinggi antara dimensi motivasi dan dimensi kegiatan, selanjutnya digunakan untuk menyusun tipe wisatawan yang bersifat hipotesis, yaitu explorer, pleasure seeker, dan adventurer. Explorer adalah tipe wisatawan yang mencari tempat-tempat menarik/indah sambil berinteraksi sosial dengan tujuan untuk membina hubungan baik dengan teman, keluarga, dan kerabat. Pleasure seeker adalah tipe wisatawan yang mencari tempat untuk bersenang-senang sambil makan-makan, berfoto, dan berbelanja. Sedangkan, adventurer adalah tipe wisatawan yang bertujuan untuk menyegarkan pikiran dengan cara mendekatkan diri dengan alam dan berpetualang.

Kelebihan dari penelitian ini adalah penelitian dilakukan dengan dua tahapan yaitu tahap eksploratif dan tahap eksplanatori. Sehingga hasil penelitian cenderung memiliki orisinalitas temuan yang tinggi. Akan tetapi, data dikumpulkan dengan metode non-random sampling. Sehingga, untuk meningkatkan reliabilitas temuan perlu penelitian replikasi dengan metode random sampling.

\section{DAFTAR PUSTAKA}

Ambrož, M., \& Ovsenik, R. (2011). Tourist Origin and Spiritual Motives. Management, 16(2), 71-86.

Assiouras, I., Skourtis, G., Koniordos, M., \& Giannopoulos, A. A. (2014). Segmenting East Asian Tourists to Greece by Travel Motivation. Asia Pacific Journal of Tourism Research, 1-22.

Bryant, F. B., \& Yarnold, P. R. (2001). Principal-Components Analysis and Exploratory and Confirmatory Factor Analysis. In L. G. Grimm, \& P. R. Yarnold, Understanding Multivariate Statistics (pp. 99-136). Woshington: American Psychological Association.

Creswell, J. W. (2003). Research Design: Qualitative, Quantitative, and Mixed Methods Approach. California: Sage Publications, Inc.

Creswell, J. W. (2006). Qualitative Inquiry and Research Design: Choosing Among Five Approaches. California: Sage Publications, Inc.

Creswell, J. W. (2012). Educational Research: Planning, Conducting and Evaluating Quantitative and Qualitative Research. Boston: Pearson Education, Inc.

Crompton, J. L. (1979). Annals of Tourism Research. Motivations for Pleasure Vacations, 408-424.

Devy, H. A., \& Soemanto, R. (2017). Pengembangan Obyek dan Daya Tarik Wisata Alam sebagai Daerah Tujuan Wisata di Kabupaten Karanganyar. Jurnal Sosiologi DILEMA, 32(1), 34-44.

Education Bureau of Hong Kong. (2013). Tourism and Hospitality Studies: Introduction to Tourism. Hong Kong: The Government of the Hong Kong Special Administrative Region.

Groat, L., \& Wang, D. (2002). Architectural Research Methods. New York: John Wiley \& Sons, Inc. .

Indonesia, R. (2009). Undang-undang Republik Indonesia Nomor 10 Tahun 2009 tentang Kepariwisataan. Jakarta: Sekretariat Negara RI.

Joseph, P. (2013). Tourism Principles, Policies \& Practices. Pondicherry: Directorate of Distance Education, Pondicherry University.

Kanfer, R. (1990). Motivation Theory and Industrial and Organizational Psychology. In M. D. Hough, Handbook of Industrial and Organizational Psychology (pp. 75-170). Palo Alto, CA: Consulting Psychologists Press.

Kementerian Pariwisata dan Badan Pusat Statistik . (2016). Statistik Profil Wisatawan Nusantara Tahun 2016. Jakarta: Kementerian Pariwisata.

Kementerian Pariwisata dan Badan Pusat Statistik. (2016). Statistik Profil Wisatawan Nusantara Tahun 2016. Jakarta: Kementerian Pariwisata.

Kementerian Pariwisata. (n.d.). Kebijakan. Retrieved 01 25, 2017, from Kementerian Pariwisata Republik Indonesia: http://www.kemenpar.go.id/asp/ringkasan.asp?c=102

Khuong, M. N., \& Ha, H. T. (2014). The Influences of Push and Pull Factors on the International Leisure Tourists' Return Intention to Ho Chi Minh City, Vietnam -A Mediation Analysis of Destination Satisfaction. International Journal of Trade, Economics and Finance, 5(6), 490-496.

Kusuma, I. G., \& Suryasih, I. A. (2016). Aktivitas Wisata Spiritual dan Motivasi Berwisata di Daya Tarik Wisata Tanah Lot Kabupaten Tabanan. Jurnal Destinasi Pariwisata, 4(2), 118-122.

Licht, M. H. (2001). Multiple Regression and Correlation. In L. G. Grimm, \& P. R. Yarnold, Reading and Understanding Multivariate Statistics (pp. 19-64). Washington: American Psychological Association. 
Mahika, E.-C. (2011). Current Trends in Tourist Motivation. Cactus Tourism Journal, 2(2), 15-24.

Marzuki. (2001). Metodologi Riset. Yogyakarta: BPFE-UII.

Mohammad, B. A.-H., \& Som, A. P. (2010). An Analysis of Push and Pull Travel Motivations of. International Journal of Business and Management, 5(12), 41-50.

Poria, Y., Butler, R., \& Airey, D. (2003). The Core of Heritage Tourism. Annals of Tourism Research, 238-254.

Rid, W., Ezeuduji, I. O., \& Pröbstl-Haider, U. (2014). Segmentation by motivation for rural tourism activities in The Gambia. Tourism Management, 40, 102-1116.

Sayangbatti, D. P., \& Baiquni, M. (2013). Motivasi dan Persepsi Wisatawan tentang Daya Tarik Destinasi terhadap Minat Kunjungan Kembali di Kota Wisata Batu. Jurnal Nasional Pariwisata, 126-136.

Song, H., \& Bae, S. Y. (2018). Understanding the Travel Motivation and Patterns of International Students in Korea: Using the Theory of Travel Career Pattern. Asia Pasific Journal of Tourism Research, 23(2), 133145.

Sung, Y.-K., Chang, K.-C., \& Sung, Y.-F. (2015). Market Segmentation of International Tourists based on Motivation to Travel: A Case Study of Taiwan. Asia Pasific Journal of Tourism Research, 1-21.

Urošević, N. (2012). Cultural Identity and Cultural Tourism -between the Local and the Global (A Case Study of Pula, Croatia). Singidunum Journal, 9(1), 67-76.

Vuuren, C. V., \& Slabbert, E. (2011). Travel Motivations and Behaviour of Tourists to a South Africa. International Conference on Tourism \& Management Studies (pp. 295-304). Algarve: The School of Management, Hospitality and Tourism of the University of the Algarve.

Yoeti, O. (1996). Pemasaran Pariwisata. Bandung: Angkasa. 